ISSN: 2224-0616

Int. J. Agril. Res. Innov. Tech. 11(1): 1-9, June 2021

DOI: https://doi.org/10.3329/ijarit.v11i1.54460
OPEN 2 ACCESS

Available online at https://ijarit.webs.com https://www.banglajol.info/index.php/IJARIT

\title{
The accuracy of PlanetScope imagery to nitrogen, phosphorus, potassium and sulfur nutrition estimation in terraced paddy field
}

\author{
Komariah*, Husnan, Mujiyo and Suryono \\ Received 17 January 2021, Revised 21 April 2021, Accepted 23 June 2021, Published online 30 June 2021
}

\section{A B S T R A C T}

This study aims to find out the accuracy of PlanetScope imagery in analyzing the total content of Nitrogen (N), Phosphorus (P), Potassium (K) and Sulfur (S) in terrace paddy field. The area for this research is terraced paddy fields in Wonosari Sub-district, Gondangrejo District, Karanganyar Regency, Central Java Province, Indonesia. Aerial photo analysis from PlanetScope (www.planet.com) was conducted at the Pedology Laboratory and Soil Survey, while soil sample analysis was carried out at the Laboratory of Chemistry and Soil Fertility, Faculty of Agriculture, Sebelas Maret University (UNS). The preparation aerial photo analysis from PlanetScope was carried out in September 2019. Soil sampling, laboratory analysis, and data analysis were carried out from September 2019 to January 2020. There are 3 Citra PlanetScope bands that have a significant effect on the elements being studied. Those three bands are band 1 (red), band 3 (blue) and band 4 (NIR). Multiple linear regression analysis obtained a regression equation model from those three bands. This model can be used as an estimator for the existence of the soil nutrient being studied. The accuracy values obtained for N, P, K and $\mathrm{S}$ in terraced paddy fields are 97.58\%; 94.85\%; $85.97 \%$; and $97.39 \%$ and the $\mathrm{R}^{2}$ value of 0.39 ; 0.30 ; 0.30 and 0.27 . The $\mathrm{R}^{2}$ value, which is still relatively small, indicates that there are many factors may affect the accuracy value.

Keywords: Remote sensing, Citra satellite, Band and terraced paddy field, Soil nutrient distribution.

Sebelas Maret University, Jalan Ir. Sutami Kentingan, Jebres, Surakarta, Jawa Tengah. Indonesia.

*Corresponding author’s email: komariah@staff.uns.ac.id (Komariah)

Cite this article as: Komariah, Husnan, Mujiyo and Suryono. 2021. The accuracy of planetscope imagery to nitrogen, phosphorus, potassium and sulfur nutrition estimation in terraced paddy field. Int. J. Agril. Res. Innov. Tech. 11(1): 1-9. https://doi.org/10.3329/ijarit.v11i1.54460

\section{Introduction}

Soil fertility is an important thing that has to be noticed in agriculture. The success of cultivating a plant is determined by soil fertility. Soil become an important factor, besides being a support for the soil plant body, it is also used as a nutrients provider for both macro and micronutrients. Macronutrients are needed by plants in larger quantities than micronutrients. Rosmarkam and Yuwono (2002) proposed that the limit for the difference of macro and micronutrients is $0.02 \%$. Macro nutrient content must more than $0.02 \%$ and if it is less then it, it is called micronutrient. This research will discuss about terraced rice fields, which it is assumed that the distribution of soil fertility not evenly distributed. This case causes inefficient fertilization given to terraced paddy fields. Fertilizers that are usually given to rice are fertilizers that contain $\mathrm{N}, \mathrm{P}, \mathrm{K}$ and $\mathrm{S}$. In a research conducted by Kaya (2019) the higher the dose of $\mathrm{N}, \mathrm{P}, \mathrm{K}$ fertilizers given, it can significantly increase the height of rice plants and it can increase the number productive tillers or clumps of rice.

Similar research has been carried out; it was mapping study of N, P, K contents in rainfed paddy field soils in Deli Serdang. This study used a grid survey method, a semi-detailed survey level; the density of observations is 1 sample for every 250 meters. The data obtained were analyzed using spatial analysis using a GIS (Geographic Information System) (Triharto et al., 2014). An agricultural system is needed to reduce intensive agricultural practices, so that the fertilization becomes efficient. Precision agriculture is a technology that can be used to reduce the intensive use of fertilizers on agricultural field. Precision agriculture is a set of technologies that combine sensors, information 
systems and information management to optimize the production by counting the variability in agricultural systems (Gebbers and Adamchuk, 2010). According to Baggio (2005), precision agriculture has focus on providing the means to observe assess and control agricultural practices, especially on applying fertilizers to the field so it can reduce intensive agricultural practices.

Farmers in intensive farming systems apply the use of inorganic fertilizers thoroughly and evenly to the field so that they often give excessive fertilizers (over-application) or under-application on some agricultural field (Chen et al., 2000) it happen because of the assumption that agriculture is a homogeneous field (Robert, 1993). In terraced field, the use of fertilizer must be adjusted according to the needs. Because the fertilizer at the top will dissolve with the water to the bottom. Therefore, it can be assumed that the soil at the bottom will be more fertile than the top. In this case, no research has been conducted using remote sensing methods to determine soil nutrient content without manual surveying.

Similar research has been conducted to find out the content of organic material in soil. In this study, an attempt was made to map the soil organic material content in South Malang by using remote sensing techniques. The remote sensing data used are Landsat TM imagery (Thematic Mapper) (bands 1, 2, 3, 4, 5, 7) and the area that has a Normalized Difference Soil Index (NDSI) value of more than 0.3 is chosen. Ground-truth data were obtained by analyzing soil organic matter content while soil samples using Black-Walkley method. The analysis results show that the use of the value of gray scale and the original imagery can be used to estimate the soil organic material content. The application of the regression equation using the original gray scale imagery value to estimate the soil organic material content shows that the soil in the study area generally contains moderate organic material content (covering $63.18 \%$ of the research area) (Sukojo and Wahono, 2002). Therefore, a research using remote sensing to determine nutrient content and distribution of soil fertility is important to do. Research on the estimation of soil fertility distribution in terraced rice fields in Wonosari Sub-district, Gondangrejo District, Karanganyar Regency has never been done before. The use of conventional methods will require a long time and expensive costs; so that we need a study on the estimation of soil fertility distribution on terraced rice fields by utilizing remote sensing methods. The choice of PlanetScope imagery in this study is because the PlanetScope imagery is a multispectral imagery that has a combination of bands in it. Each band has its own function. Multispectral data based on CubeSat, daily PlanetScope Citra with a spatial resolution of $3.125-\mathrm{m}$, downloaded from the Planet Lab website (www.planet.com), which contains four bands namely the blue band (455$515 \mathrm{~nm}$ ), the green band $(500-590 \mathrm{~nm})$, the red band $(590-670 \mathrm{~nm})$, and the NIR band $(780-$ $860 \mathrm{~nm})$. The data is in the form of a digital number from each band (Cai et al., 2019). This Citra is very suitable for this research because the area in this research is not too large. Until now, it is still very rare to find the use of PlanetScope imagery to estimate soil nutrients, especially in terraced paddy fields. Therefore, this research aims to estimate the content of N, P, K and S elements in terraced paddy fields in Wonosari Sub-district, Gondangrejo District, Karanganyar Regency, Central Java.

\section{Materials and Methods}

\section{Place and time of research}

The research is located in Wonosari Sub-district, Gondangrejo District, Karanganyar Regency, which the areas have Inceptisol soil types. Located at an altitude of 267 meters above sea level and located at $7^{\circ} 29^{\prime} 50$ "South Latitude and $110^{\circ} 51^{\prime} 26^{\prime \prime}$ East Longitude, is presented in Fig. 1. Aerial photo of 19 September 2019 from the location, taken from PlanetScope imagery (www.planet.com). Meanwhile, soil sampling, laboratory analysis, and data analysis were carried out from September 2019 to January 2020. Determination of sample points begins with taking aerial photographs from Google Earth and creating an altitude map using the Global Mapper. The results obtained from the Global Mapper are used to determine sample points. Imagery analysis was done using ENVI and ArcGis Applications 10.4.

Terraced paddy fields obtained from the analysis have an altitude of 96, 98, 100, 102, 104, 106, 108, and 112 masl. Soil samples were taken based on the terrace (Fig. 2), the terraces with a height of 96-98 masl (2 points), 98-100 masl (2 points), 100-102 masl (6 points), 102-104 masl (5 points), 104-106 masl (2 points), 106-108 masl (3 points), 108-110 masl (3 points), and 112-114 masl (2 points). The total is 25 sample points. Soil samples were taken using a drill or hoe to the depth of $0-20 \mathrm{~cm}$, which is a layer of field soil cultivation. The coordinates of each sampling location are recorded with the help of GPS. Besides soil sampling, observation of the condition of the sample location is also carried out by observing the type of field usage and other parameters that may affect soil fertility in the area. The variables analyzed in the laboratory were $\mathrm{N}, \mathrm{P}, \mathrm{K}$ and $\mathrm{S}$ of the soil. 


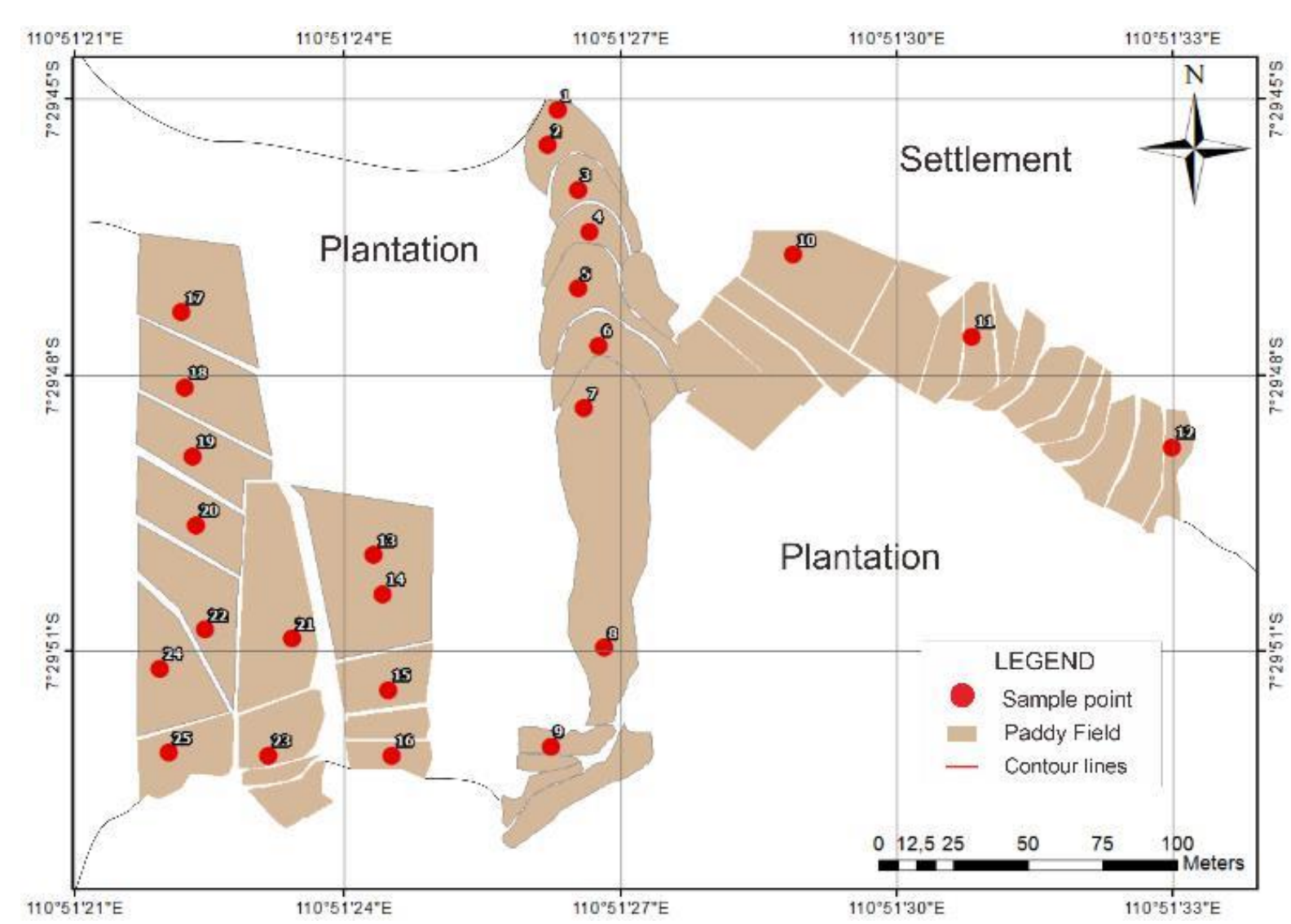

Fig. 1. Research Map Location.

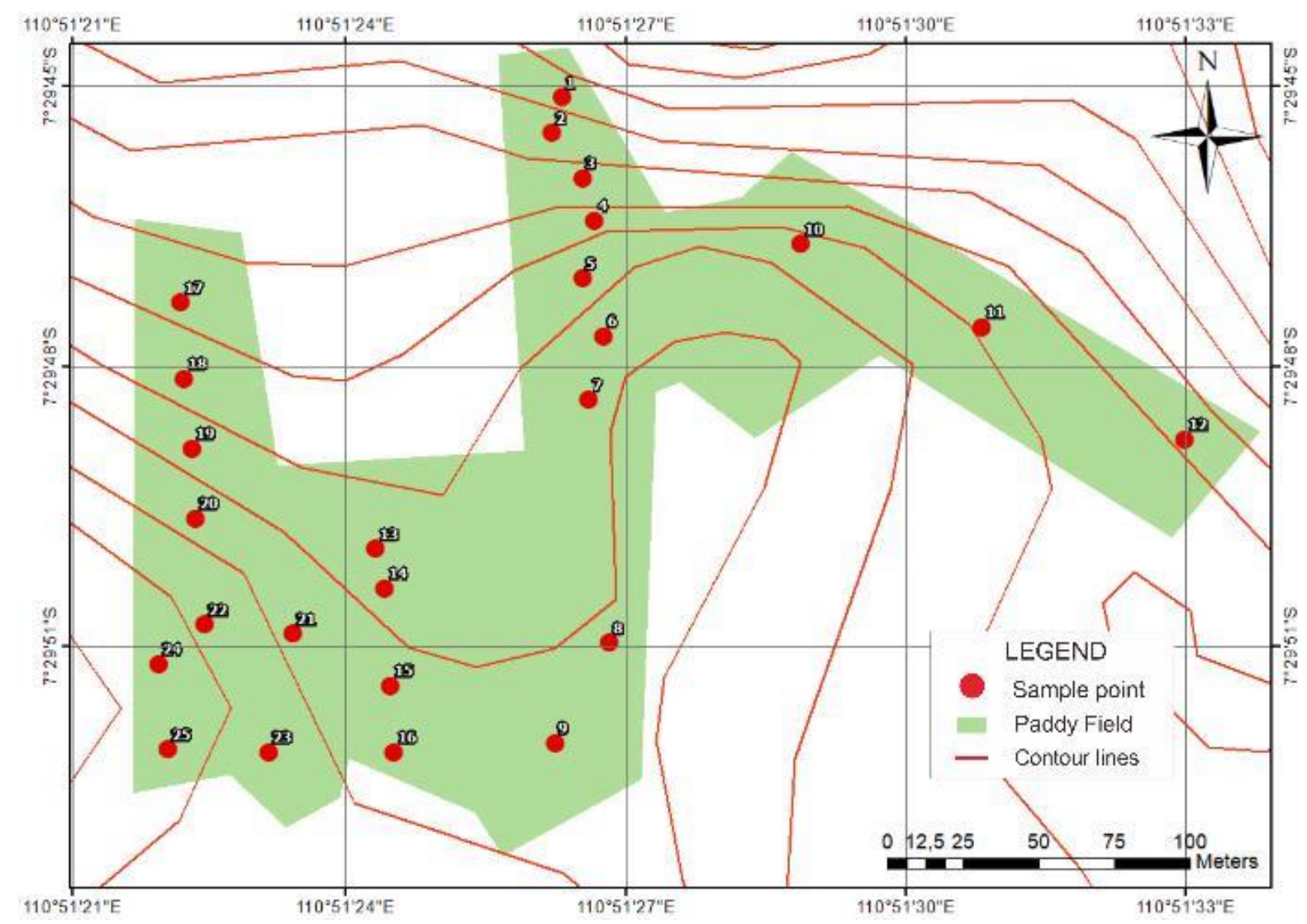

Fig. 2. Contour Map. 


\section{Independent variable}

The independent variables observed were digital number from Planetscope imagery included red, green, blue and NIR bands. The application used in this analysis is ENVI, which is used to cut the Citra according to the required area. To get the color digital number value, use extension from the ArcGis 10.4 application, that is identification of color chroma (Red, Green, Blue and NIR). By using this extension, a detailed color digital number value will be seen which is used as independent data for multiple linear regression analysis.

In multiple linear regression analysis, digital number data functions as an independent variable. The data was taken in line with the number of sample points to be sampled in the field. In this study, 25 sample points were taken from the observed field soil. The digital number data from the Citra PlanetScope is analyzed through the ArcGis 10.4 application.

\section{Dependent variable}

Dependent variables in this study were soil N, P, $\mathrm{K}$ and $\mathrm{S}$ content. Analysis of soil $\mathrm{N}$ elements was carried out by destruction, distillation and then the results were measured using a spectrophotometer. Destruction is carried out by weighing $0.5 \mathrm{~g}$ of soil samples $<0.5 \mathrm{~mm}$, then put it into the digest tube. Add $1.0 \mathrm{~g}$ mixture of selenium and $3 \mathrm{ml}$ of concentrated sulfuric acid, destructed to $350^{\circ} \mathrm{C}$ (3-4 hours). The destruction is complete when white steam comes out and a clear extract is obtained (about 4 hours). Took the tube, cooled it down and then the extract was diluted with ion-free water to exactly $50 \mathrm{ml}$. Shook it until it became homogeneous, left it overnight so that the particles settled. The extract was used for $\mathrm{N}$ measurement by distillation or colorimetric method.

The measurement of $\mathrm{N}$ by distillation by qualitatively transferred all sample extracts into a boiling flask (use ion-free water and spray flask). Added a little boiling stone powder and water to half the volume of the flask. Prepared a container for releasing $\mathrm{N}$, it was Erlenmeyer, which contains $10 \mathrm{ml}$ of $1 \%$ boric acid plus three drops of Conway indicator (colored red) and connected to a distillation device. With a measuring cup, added $10 \mathrm{ml}$ of $40 \% \mathrm{NaOH}$ to the boiling flask containing the sample and immediately closed it. Distilled until the volume of the container reached $50-75 \mathrm{ml}$ (green). The distillate was titrated with $0.050 \mathrm{~N} \mathrm{H}_{2} \mathrm{SO}_{4}$ until it became pink. Record the volume of the sample titar (Vc4) and blanko (V).

Measurement of $\mathrm{N}$ with a spectrophotometer began with pipetting into the reactor tube $2 \mathrm{ml}$ each of the extract and standard row. Added $4 \mathrm{ml}$ of Tartrat and Na-phenate, shook and let it for 10 minutes. Added $4 \mathrm{ml}$ of $5 \% \mathrm{NaOCl}$, shook it and measured it with a spectrophotometer at a wavelength of $636 \mathrm{~nm}$ after 10 minutes of giving this reagent.

Note: The indophenol blue colored that formed is less stable. Try to obtain the same time between reagent application and measurement for each standard row and sample.

$\mathrm{P}$ and $\mathrm{K}$ analysis were performed with $25 \% \mathrm{HCL}$ extract. Weigh 2,000 g of soil sample $<2 \mathrm{~mm}$, put in a shake bottle and added $10 \mathrm{ml}$ of $25 \% \mathrm{HCl}$ then shook with shaking machine for 5 hours. Put into the reactor tube left overnight or centrifuged. Pipette $0.5 \mathrm{ml}$ of sample clear extract into the reactor tube. Add $9.5 \mathrm{ml}$ of ion-free water $(20 \mathrm{x}$ dilution) and shook it. A $2 \mathrm{ml}$ pipette of the dilute sample extract and the standard row were each added into a reactor tube, then $10 \mathrm{ml}$ of dye reagent $P$ solution was added and shaken. Left for 30 minutes and then measure the absorbance with a spectrophotometer at a wavelength of 889 $\mathrm{nm}$. For potassium, the liquid sample extract and the standard row $\mathrm{K}$ were measured directly by means of an AAS emission.

Sulphur (S) was analyzed by determining the macro and micro elements with wet ashing, the reagents used were concentrated HNO3 (65\%) and concentrated $\mathrm{HClO}_{4}$ (65\%). By weighing 0.5 $\mathrm{g}$ of fine soil sample $<0.5 \mathrm{~mm}$ into the digest tube, $5 \mathrm{ml}$ of p.a nitric acid and $0.5 \mathrm{ml}$ p.a perchloric acid are added, left it overnight. The next day it is heated at $100^{\circ} \mathrm{C}$ for 1 hour 30 minutes, then the temperature is increased to $130^{\circ} \mathrm{C}$ for 1 hour, the temperature is increased again to $150^{\circ} \mathrm{C}$ for 2 hours 30 minutes (until the yellow steam runs out, if there is still yellow steam, add more heating time), after the yellow steam run out the temperature is increased to $170^{\circ} \mathrm{C}$ for 1 hour, then the temperature is increased to $200^{\circ} \mathrm{C}$ for 1 hour (until white steam is formed). The destruction is completed by the formation of a white precipitate or a clear solution of about $0.5 \mathrm{ml}$. The extract was cooled and then diluted with ion-free water to $25 \mathrm{ml}$, then shook it until homogeneous, left overnight.

\section{Analysis strategy}

To build an estimation model based on N, P, K and $\mathrm{S}$ value data on the soil from laboratory results as the dependent variable with a combination of color digital numbers from the results of the PlanetScope imagery analysis as an independent variable, multiple linear regression analysis is used. This analysis produces the best equation model to estimate the value of $\mathrm{N}, \mathrm{P}, \mathrm{K}$ and $\mathrm{S}$ on the soil. The analysis was conducted using the Minitab application. 
Meanwhile, the test for the accuracy of the N, P, $\mathrm{K}$ and $\mathrm{S}$ content estimation models in the soil was conducted by using several calculations, there are standard deviation, Standard Error Estimate (SE), min. \% error, max. \% error, minimum accuracy and maximum accuracy. The formula used is as follows:

$\hat{\mathrm{y}}=\frac{\Sigma y}{n}$

Standard Deviation $=\sqrt{\frac{\Sigma y^{2}-\frac{\Sigma(y)^{2}}{n}}{n-1}}$

SE Estimate $=\sqrt{\frac{\Sigma\left(\mathrm{y}^{\prime}-y\right)^{2}}{n-1}}$

$\mathrm{CL}=1-\alpha$

Bottom $=\hat{y}-\mathrm{CL}$

Upper $=\hat{y}+C L$

Table 1. Digital number of each band.
Min. \% Error $=\mathrm{SE} / \mathrm{Upper} \times 100 \%$

Max. \% Error $=$ SE/Bottom $\times 100 \%$

Min. Accuracy $=100 \%-$ Max \% Error

Max. Accuracy = 100\%-Min \% Error

Note:

SE = Standard Error of Estimate

y' $\quad=$ Soil nutrient values from the model

$\mathrm{y}=$ Soil nutrient values from the laboratory

$\mathrm{n} \quad=$ number of sample

a $\quad=0.05$

\section{Results and Discussions}

\section{Digital number}

The digital number of each band from PlanetScope imagery is presented in Table 1.

\begin{tabular}{|c|c|c|c|c|c|c|c|c|c|}
\hline $\begin{array}{c}\text { Sample } \\
\text { Point }\end{array}$ & \multicolumn{3}{|c|}{ Digital Number } & \multicolumn{3}{c|}{ Sample } & \multicolumn{3}{c|}{ Digital Number } \\
\hline 1 & 8999 & 7755 & 6838 & 8979 & 14 & 9191 & 7669 & 7016 & 6622 \\
\hline 2 & 9447 & 8464 & 7981 & 9057 & 15 & 9662 & 8407 & 8276 & 9307 \\
\hline 3 & 9942 & 8817 & 7948 & 8155 & 16 & 10089 & 8921 & 8946 & 9622 \\
\hline 4 & 9756 & 8430 & 7875 & 7579 & 17 & 8735 & 6942 & 6216 & 6496 \\
\hline 5 & 9346 & 7687 & 6619 & 5903 & 18 & 9499 & 8212 & 7811 & 7768 \\
\hline 6 & 9298 & 7652 & 6656 & 6252 & 19 & 9834 & 8508 & 8571 & 8972 \\
\hline 7 & 9601 & 7946 & 6811 & 6268 & 20 & 9476 & 8383 & 8251 & 8528 \\
\hline $\mathbf{8}$ & 9137 & 7827 & 6855 & 6472 & 21 & 9872 & 8727 & 8487 & 8820 \\
\hline 10 & 8487 & 6701 & 5379 & 5625 & 22 & 9901 & 9177 & 9238 & 9583 \\
\hline 11 & 8681 & 6831 & 5719 & 5534 & 23 & 9614 & 8688 & 8714 & 8829 \\
\hline 13 & 9701 & 8157 & 7420 & 7387 & 24 & 9743 & 8746 & 8793 & 9360 \\
\hline
\end{tabular}

From Table 1, it can be seen that the digital number for the red band ranges from 8999 to 10089, while the green band also varies from 6701 to 9177 . Then the digital number for the blue and NIR bands also varies, ranging from
5379 to 9238 and 5903 to 9622 while the results of laboratory analysis of the soil $\mathrm{N}, \mathrm{P}, \mathrm{K}$ and $\mathrm{S}$ content of each sample point are presented in Table 2.

Table 2. Results of Laboratory Analysis of N, P, K and S Soil nutrients.

\begin{tabular}{|c|c|c|c|c|c|c|c|c|c|}
\hline $\begin{array}{l}\text { Sample } \\
\text { point }\end{array}$ & N\% & S \% & $\begin{array}{c}\mathrm{P} \\
\left(\mathrm{mg} \operatorname{100g}^{-1}\right)\end{array}$ & $\begin{array}{c}\mathrm{K} \\
\left(\mathrm{mg} \operatorname{100g}^{-1}\right)\end{array}$ & $\begin{array}{c}\text { Sample } \\
\text { point }\end{array}$ & N \% & S \% & $\begin{array}{c}\mathrm{P} \\
\left(\mathrm{mg} \operatorname{10og}^{-1}\right)\end{array}$ & $\begin{array}{c}\mathrm{K} \\
\left(\mathrm{mg} \operatorname{100g}^{-1}\right)\end{array}$ \\
\hline 1 & 0.20 & 0.09 & 11.40 & 83.34 & 14 & 0.10 & 0.07 & 22.99 & 51.30 \\
\hline 2 & 0.19 & 0.10 & 16.53 & 77.84 & 15 & 0.13 & 0.41 & 26.75 & 67.52 \\
\hline 3 & 0.11 & 0.10 & 21.43 & 53.93 & 16 & 0.18 & 0.29 & 23.68 & 66.43 \\
\hline 4 & 0.12 & 0.06 & 21.34 & 56.44 & 17 & 0.12 & 0.09 & 21.36 & 56.13 \\
\hline 5 & 0.12 & 0.10 & 21.63 & 67.07 & 18 & 0.15 & 0.09 & 25.50 & 69.80 \\
\hline 6 & 0.13 & 0.09 & 19.45 & 52.39 & 19 & 0.13 & 0.17 & 18.38 & 82.03 \\
\hline 7 & 0.13 & 0.12 & 21.59 & 52.66 & 20 & 0.14 & 0.32 & 23.54 & 61.40 \\
\hline 8 & 0.15 & 0.09 & 24.60 & 57.04 & 21 & 0.15 & 0.03 & 21.42 & 64.42 \\
\hline 9 & 0.06 & 0.06 & 15.01 & 56.10 & 22 & 0.15 & 0.04 & 16.41 & 57.09 \\
\hline 10 & 0.11 & 0.05 & $13.5^{8}$ & 52.47 & 23 & 0.15 & 0.03 & 23.28 & 52.34 \\
\hline 11 & 0.18 & 0.10 & 25.74 & 56.04 & 24 & 0.15 & 0.03 & 23.28 & 52.34 \\
\hline 12 & 0.12 & 0.13 & 23.79 & 51.27 & 25 & 0.11 & 0.04 & 20.42 & 53.33 \\
\hline 13 & 0.13 & 0.12 & 20.63 & 53.58 & & & & & \\
\hline
\end{tabular}

Table 2 shows that the values of Nitrogen and Sulfur not have too large data variation, that is 0.10-0.20 (average 0.13) and 0.03-0.41 (average o.11), respectively. It is different from phosphorus and potassium, which have quite diverse data variations, respectively 11.40-26.75 (average 20.94) and 51.27-83.34 (average 60.17). This can affect the amount of accuracy value and 
the determinant coefficient obtained in the multiple linear regression model. Multiple linear regression was conducted, using the dependent variable (laboratory data) and the independent variable (digital number data from PlanetScope imagery). Correlation analysis between digital number data from images with laboratory analysis data is important to be done before multiple linear regression analysis. This is done to determine the band from the image that is significantly correlated with the element under study. The results of the correlation analysis are presented in Table 3.

Table 3. Pearson's correlation digital number images with nutrients of N, P, K and S.

\begin{tabular}{|c|c|c|c|c|}
\hline Band & $\mathrm{N}$ & $\mathrm{P}$ & K & S \\
\hline & $\begin{array}{c}\mathrm{p} \text {-value } \\
(\mathrm{r})\end{array}$ & $\begin{array}{c}\text { p-value } \\
\text { (r) }\end{array}$ & $\begin{array}{c}\text { p-value } \\
(\mathrm{r})\end{array}$ & $\begin{array}{c}\text { p-value } \\
\text { (r) }\end{array}$ \\
\hline Band 1 (red) & $\begin{array}{c}<0.01 \\
(0.398)\end{array}$ & $\begin{array}{c}<0.01 \\
(0.393)\end{array}$ & $\begin{array}{c}0.202 \\
(0.152)\end{array}$ & $\begin{array}{c}0.045 \\
(0.237)\end{array}$ \\
\hline Band 2 (green) & $\begin{array}{c}<0.01 \\
(0.440)\end{array}$ & $\begin{array}{c}<0.01 \\
(0.312)\end{array}$ & $\begin{array}{c}0.112 \\
(0.189)\end{array}$ & $\begin{array}{c}0.089 \\
(0.202)\end{array}$ \\
\hline Band 3 (blue) & $\begin{array}{c}<0.01 \\
(0.424)\end{array}$ & $\begin{array}{c}<0.01 \\
(0.320)\end{array}$ & $\begin{array}{c}0.049 \\
(0.232)\end{array}$ & $\begin{array}{c}0.049 \\
(0.277)\end{array}$ \\
\hline Band 4 (NIR) & $\begin{array}{c}<0.01 \\
(0.546)\end{array}$ & $\begin{array}{c}0.04 \\
(0.301)\end{array}$ & $\begin{array}{c}<0.01 \\
(0.432)\end{array}$ & $\begin{array}{c}<0.01 \\
(0.330)\end{array}$ \\
\hline
\end{tabular}

Note: Light blue cell means significant different at $\alpha=0.05$

Based on Table 3, it can be seen that each band of the $\mathrm{N}$ element in all bands has a very real relation. The $\mathrm{P}$ element has a very real relation with band 1, 2 and 3 and a real relation with band 4.The $\mathrm{K}$ element only has a real relation with band 3 and very real with band 4 , while the $\mathrm{S}$ element has a real relation with band 1, 3 and very real with band 4 . Because there is a band that has a significant effect on the observed element, further statistical analysis is conducted using multiple linear regression analysis. Multiple linear regression analysis is used to obtain equations in estimating the content of $\mathrm{N}$, $\mathrm{P}, \mathrm{K}$ and $\mathrm{S}$ elements and knowing the existence of multicollinearity symptoms. Multicollinearity can be seen based on the high value of VIF of the regression analysis, as presented in Table 4.

Table 4. Multicollinearity analysis (VIF) of band and element of multi-regression analysis.

\begin{tabular}{|c|c|c|c|c|}
\hline \multirow[t]{2}{*}{ Band } & \multicolumn{4}{|c|}{ VIF } \\
\hline & $\mathrm{N}$ & $\mathrm{P}$ & K & S \\
\hline Band 1 (red) & 10.32 & 6.75 & - & 6.10 \\
\hline Band 2 (green) & 24.52 & 22.73 & - & - \\
\hline Band 3 (blue) & 22.37 & 14.40 & 4.68 & 17.10 \\
\hline Band 4 (NIR) & 7.65 & 7.65 & 4.68 & 7.01 \\
\hline
\end{tabular}

The results of the multicollenearity analysis are presented in the Table 4. Multicollinearity is indicated by a VIF value of more than 10. Then, after performing multiple linear regression analysis, the equation models were obtained (data are not presented) with multicollinearity in the regression. So that those equation models can't be used accurately. Multicollinearity occurs due to the high value of the Variance Inflation Factor (VIF) shown in Table 5 of some of those bands. A high VIF value is shown in the $\mathrm{N}$ regression with the obtained VIF value of 10.32 for band 1 (red); 24.52 for band 2 (green); and
22.37 for band 3 (blue). In the $\mathrm{P}$ regression the VIF value obtained was 22.73 in band 2 (green) and 14.40 in band 3 (blue). The $S$ element regression obtained a high VIF value in band 3 (blue) that is 17.01. For the selection of the best regression model, several methods are commonly used. Two of them are Stepwise and All Possible Regression (Best Subset Regression) (Hanum, 2011). Therefore, it is necessary to do the best subset analysis to minimize the multicolliniarity. Based on the analysis that has been carried out, it is obtained a regression equation model, which is presented in Table 5 .

Table 5. Linier regression equation to predict soil element with band's digital number and accuracy.

\begin{tabular}{|c|c|c|c|}
\hline Parameter & Equations & $\mathrm{R}^{2}$ & Max accuracy (\%) \\
\hline $\mathrm{N}$ & $=-0.315+0.000057 \mathrm{R}-0.000040 \mathrm{~B}+0.000028 \mathrm{IR}$ & 0.39 & $97 \cdot 58$ \\
\hline $\mathrm{P}$ & $=3.14+0.006029 \mathrm{~B}-0.003639 \mathrm{IR}$ & 0.30 & 94.85 \\
\hline K & $=53.00-0.00726 \mathrm{~B}+0.00800 \mathrm{IR}$ & 0.30 & 85.97 \\
\hline $\mathrm{S}$ & $=-0.251+0.000063 \mathrm{R}-0.000050 \mathrm{~B}+0.000014 \mathrm{IR}$ & 0.27 & 97.39 \\
\hline
\end{tabular}


Table 5 shows that the value of $\mathrm{N}$ and $\mathrm{S}$ can be estimated from the combination of band 1 (red), band 3 (blue) and band 4 (NIR). $\mathrm{P}$ and $\mathrm{K}$ values can be estimated through band 3 (blue) and band 4 (NIR). Each of these models has a different coefficient of determination $\left(\mathrm{R}^{2}\right)$. The higher the $\mathrm{R}^{2}$ value, the more accurate the resulting model will be. The coefficient of determination $\left(\mathrm{R}^{2}\right)$ of $\mathrm{N}, \mathrm{P}, \mathrm{K}$ and $\mathrm{S}$ is $39.00 \%$; $30.01 \%$; $30.20 \%$ and

(a)

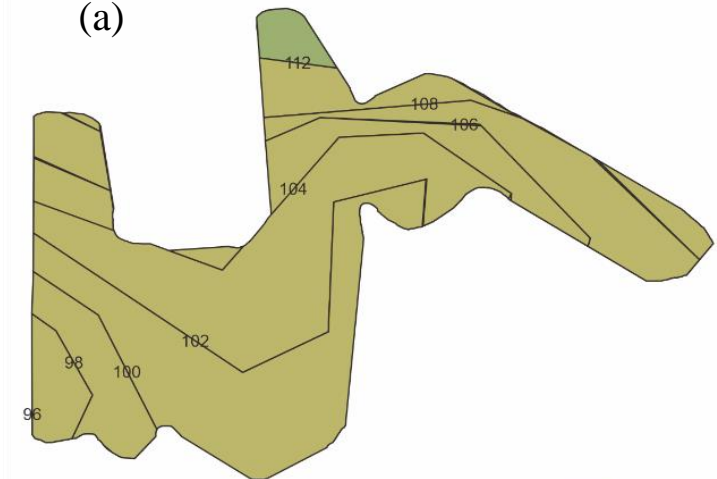

27.20\%. In addition to calculating $\mathrm{R}^{2}$, the maximum accuracy value of the model is calculated in order to determine the maximum percentage of the model in estimating the N, P, K and $\mathrm{S}$ content of field soil. The results of the analysis show that the maximum accuracy value of each element is $97.58 \%$ for the $\mathrm{N}$ value; $94.85 \%$ for the $\mathrm{P}$ value; $85.97 \%$ for the $\mathrm{K}$ value and $97.39 \%$ for the $\mathrm{S}$ value.

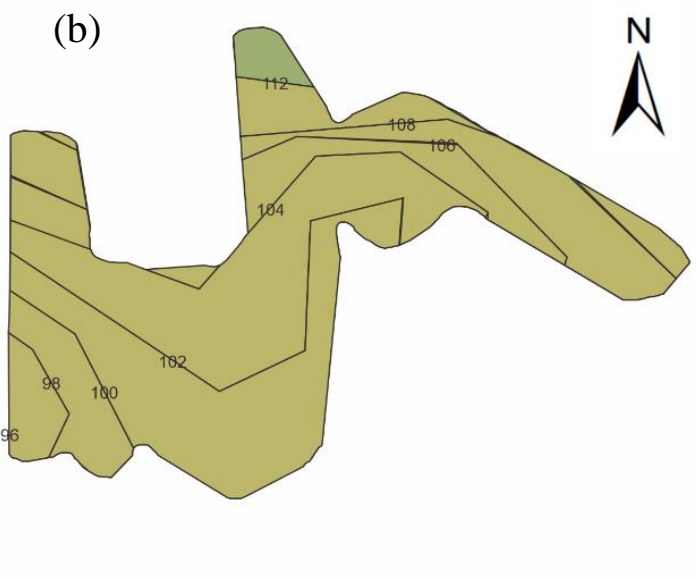

Fig. 3. Actual (a) and Predicted (b) Nitrogen Distribution.
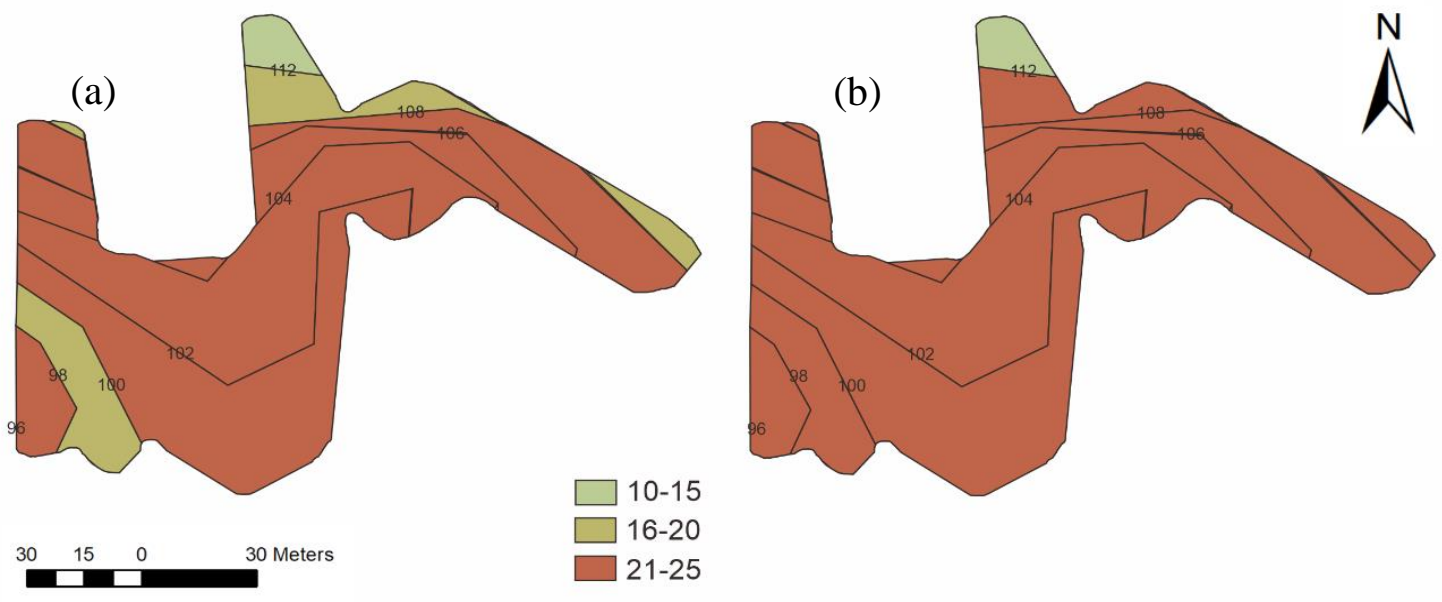

Fig. 4. Actual (a) and Predicted (b) Phosphorus Distribution.
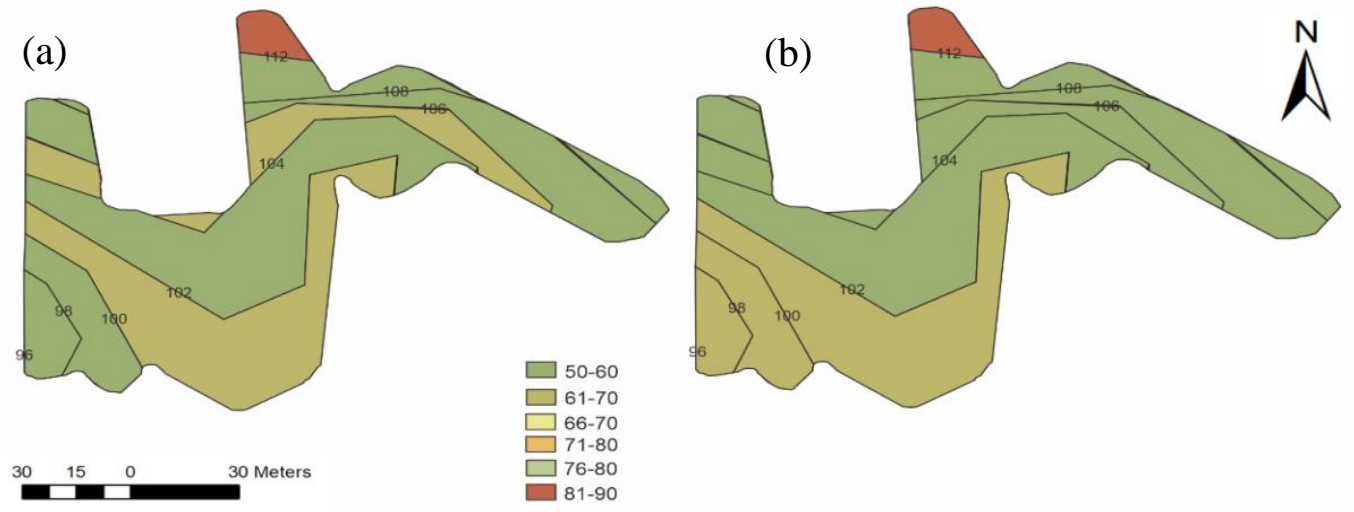

Fig. 5. Actual (a) and Predicted (b) Potassium Distribution. 

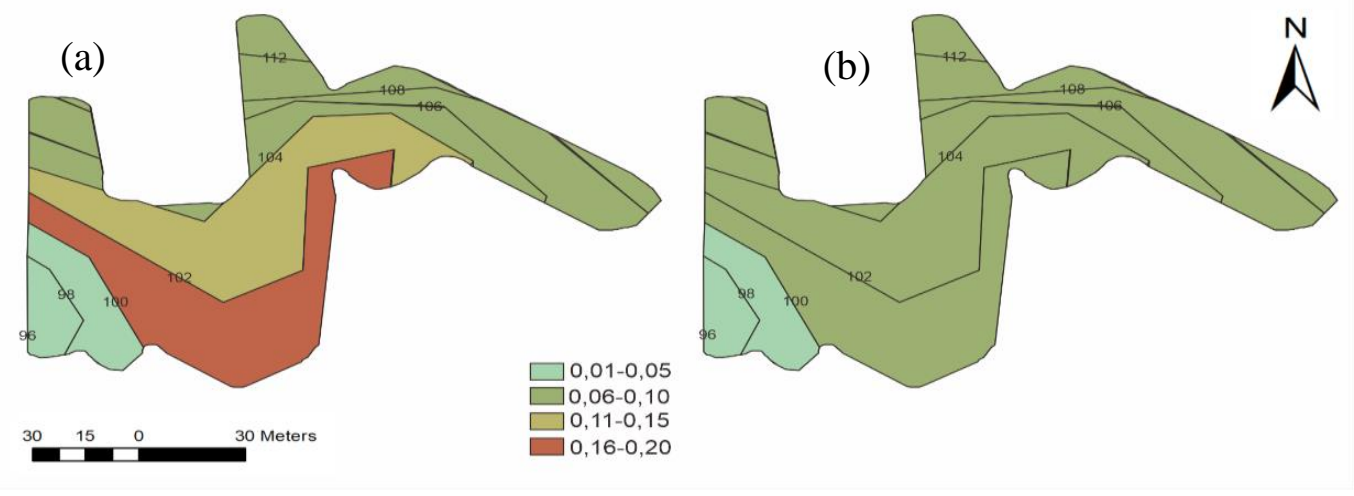

Fig. 6. Actual (a) and Predicted (b) Sulphur Distribution.

Based on Figures 3 to 6 , it shows a map of the differences in the content of elements N, P, K and $\mathrm{S}$ between the actual value from laboratory analysis and the predicted value from the PlanetScope imagery. From these results, it can be seen that the actual and estimated values of $\mathrm{N}$ are the same (Fig. 3), while the predicted $P$ values differ from the actual values, especially on terraces with an altitude of 98-100 and 108-112 masl. Different K content at an altitude of 104106 and 96-100 masl and different $\mathrm{S}$ at an altitude of 100-104 masl. The closest result is the analysis of nitrogen content in terraced paddy fields.

The estimation of $\mathrm{N}, \mathrm{P}, \mathrm{K}$ and $\mathrm{S}$ content in terraced paddy fields with PlanetScope imagery has high accuracy as shown in table 5 , which was $97.58 ; 94.85 ; 84.97$; and 97.39 , respectively. However, Table 5 also shows the low determinant coefficient $\left(\mathrm{R}^{2}\right)$, which is $39.00 \%$; $30.10 \%$; $30.20 \%$ and $27.20 \%$ for $\mathrm{N}, \mathrm{P}, \mathrm{K}$ and $\mathrm{S}$, respectively, resulting in differences in the distribution of these elements (Figures 3-6). The coefficient of determination $\left(\mathrm{R}^{2}\right)$ is used to measure how far the model's ability to explain variations in the independent variable (Ghozali, 2013). According to Sugiyono (2015), independent variables are variables that influence or cause the dependent variable. This coefficient of determination is used because it can explain the excellence level of the regression model in predicting the dependent variable. The coefficient of determination value is between zero and one.

The insignificant correlation between the element $\mathrm{K}$ and the 2 bands (Red and Green) (Table 4) may cause a high variation/difference in the distribution of elemental K content (Fig. 5). Meanwhile, the significant correlation in all bands with $\mathrm{N}$ and $\mathrm{P}$ elements has an effect on the minimal variation in the content of $\mathrm{N}$ and $\mathrm{P}$ elements in all terraces. The equation generated in Table 5 also shows that not all bands can be used to predict soil nutrient elements, with the VIF value as an indicator (Table 5). A high VIF value can cause multicollinearity so that the estimation results are less accurate.
Multicollinearity testing aims to determine whether the regression model found a correlation in independent variables (Ghozali, 2016). The low $\mathrm{S}$ content in the soil assumed to make the accuracy and determinant coefficient of the estimator equation smaller even though the VIF value is not too large. In the soil the $\mathrm{S}$ content ranges from 0.01-0.20\% (Winarso, 2005). Hanafiah (2005) states that the sulfur content in the earth's crust is $0.06 \%$. At the location of this research, the average soil sulfur content was $0.11 \%$.

The maximum accuracy value from the estimation of soil N, P, K and S with PlanetScope imagery is quite high (85.97-97.58\%) as shown in table 5 , but $\mathrm{R}^{2}$ is low (0.27-0.39). Even though the accuracy is quite good, the model obtained still cannot be applied directly. The low $\mathrm{R}^{2}$ value in all models is a sign that many other factors can affect the model's accuracy.

Based on the results obtained, the actual and most accurate prediction values are the estimation results of total soil nitrogen, as seen in Fig. 3. This can be proven by the calculation of the maximum accuracy and the determinant coefficient on $\mathrm{N}$, which is the highest result than $\mathrm{P}, \mathrm{K}$ and $\mathrm{S}$. It can be caused by the fact that the amount of soil $\mathrm{N}$ is higher than $\mathrm{P}, \mathrm{K}$ and $\mathrm{S}$. Total $\mathrm{N}$ is a macro element that is needed by plants in large quantities and makes up $1.5 \%$ of the plant weight. $\mathrm{N}$ has functions in the formation of protein (Hanafiah, 2005). Listed in table 5, the maximum accuracy percentage for $\mathrm{N}$ is $97.58 \%$ with a determinant coefficient of 0.39 . Phosphorus and potassium have a determinant coefficient of 0.30. With this value, although the maximum accuracy is quite high, there are still differences in the actual and predicted values for the two elements. In the total soil sulfur element with a maximum accuracy value of $97.39 \%$, there are still differences in the actual and predicted values. It marked by the low $\mathrm{R}^{2}$ value of $27.2 \%$. This can be caused by the small total sulfur value in the soil as listed in Table 2. The laboratory results show that the average sulfur content is almost the same. 
Thus, PlanetScope satellite imagery can be used as a reference for paddy field management planning, especially in relation to efficient fertilization using satellite imagery. In paddy cultivation, there is a need for adequate field preparation and good monitoring of planting. According to Dirgahayu et al. (2014), continuous monitoring of paddy plants is needed to predict the harvest area that will be obtained during 1 planting period or within a certain period of time as information that is needed, especially by the Government of Indonesia in maintaining the stability of food security. According to Wahyunto et al. (2006), the paddy plant is a food plant group that is very important and beneficial to the life of the Indonesian people. However, there needs to be a more in-depth study of the use of these images. One of the basic information needed for agricultural development is spatial data (maps) of potential field resources, which provide important information about the distribution, area, field suitability, limiting factors, and alternative technologies that can be applied (Suryana et al., 2005). Remote Sensing Satellite Imagery and Geographic Information System (GIS) are spatial technologies that are very useful in agricultural planning. The use of satellite imagery is considered to be more efficient, fast, precise and cost-effective. One of the demands and challenges of agricultural management in Indonesia is the mastery of science and technology (Tri et al., 2015). The results of this research are expected to be easily adopted by the community in conducting land management planning.

\section{Conclusion}

The accuracy of the PlanetScope imagery for estimating $\mathrm{N}, \mathrm{P}, \mathrm{K}$ and $\mathrm{S}$ contents in terraced paddy fields was rather high, ranged from 85.97 to $97.58 \%$. However, further studies on bigger elevation differences with bigger observation area are necessary to identify the accuracy.

\section{References}

Baggio, A. 2005. Wireless sensor networks in precision agriculture. Netherlands IEEE Pervasive Comput. 3.

Cai, Y., Guan, K., Nafziger, E., Chowdhary, G., Peng, B., Jin, Z. and Wang, S. 2019. Detecting in-season crop nitrogen stress of corn for field trials using UAV-and CubeSatbased multispectral sensing. IEEE J. Selected Topics Appl. Earth Observ. Remote Sens. 12(12): 5153-5166.

https://doi.org/10.1109/JSTARS.2019.2953489

Chen, C.Y., Stemberger, R.S., Klaue, B., Blum, J.D., Pickhardt, C. and Folt, C.L. 2000. Accumulation of heavy metals in food web components across a gradient of lakes. Limnol. Oceanogr. 45(7): 1525-1536. https://doi.org/10.4319/lo.2000.45.7.1525
Dirgahayu, D., Noviar, H. and Silvia. 2014. Model Pertumbuhan Tanaman Padi di Pulau Sumatera Menggunakan Data EVI Modis Multitemporal. Prosiding Seminar Nasional Penginderaan Jauh. Bogor. p. 2.

Gebbers, R. and Adamchuk, V.I. 2010. Precision Agriculture and Food Security. Sci. 327(5967): 828-831.

https://doi.org/10.1126/science.1183899

Ghozali, I. 2013. Aplikasi Analisis Multivariate Dengan Program IBM SPSS 21Update PLS Regresi. Semarang: Badan Penerbit Universitas Diponegoro. pp. 93-96.

Ghozali, I. 2016. Aplikasi Analisis Multivariete IBM SPSS. In Semarang, Universitas Diponegoro. pp. 105-109.

Hanafiah, K.A. 2005. Dasardasar Ilmu Tanah. PT Raja Grafindo Persada. Jakarta. pp. 275-307.

Hanum, H. 2011. Perbandingan metode stepwise, best subset regression, dan fraksi dalam pemilihan model regresi berganda terbaik. Jurnal Penelitian Sains. 14(2): 14201(1-6). https://doi.org/10.26554/jps.v14i2.109

Kaya, E. 2019. Pengaruh Kompos Jerami Dan Pupuk NPK Terhadap N-Tersedia Tanah, Serapan-N, Pertumbuhan, Dan Hasil Padi Sawah (Oryza sativa L). Agrologia. 2(1): 4350. https://doi.org/10.30598/a.v2i1.277

Robert, P. 1993. Characterization of soil conditions at the field level for soil specific management. Geoderma. 60(1-4): 57-72. https://doi.org/10.1016/0016-7061(93)90018-G

Rosmarkam, A. and Yuwono, N.W. 2002. Ilmu Kesuburan Tanah. In Kanisius. p. 31.

Sugiyono. 2015. Metode Penelitian Pendidikan Pendekatan Kuantitatif, Kualitatif, dan R \& D. Bandung: Alfabeta. pp. 38-41.

Sukojo, B.M. and Wahono. 2002. Pemanfaatan Teknologi Penginderaan Jauh Untuk Pemetaan Kandungan Bahan Organik Tanah. Makara, Teknologi. 6(3): 102-112.

Suryana, A., Adimihardja, A., Mulyani, A., Hikmatullah and Siswanto, A.B. 2005. Prospek dan Arah Pengembangan Agribisnis: Tinjauan aspek kesesuaian lahan. Badan Penelitian dan Pengembangan Pertanian, Jakarta. pp. 1-2.

Tri, A., Wibowo, T.A. and Permana, A.G. 2015. Pengelolaan Padi Di Pulau Jawa Berbasis Web Application of Geographic Information System (GIS) for Management. EProceeding of Applied Science. p. 2.

Triharto, S., Musa, L. and Sitanggang, G. 2014. Survey dan Pemetaan Unsur Hara N, P, K dan $\mathrm{pH}$ Tanah Hujan di Desa Durian Kecamatan Pantai Labu. Online Agroekoteknologi. pp. 2-3.

Wahyunto, Widagdo and Heryanto, B. 2006. Pendugaan produktivitas tanaman padi sawah melalui analisis citra satelit. Informatika Pertanian. 15: 653-869.

Winarso. 2005. Kesuburan Tanah Dasar Keseh atan Dan Kualitas Tanah. Gava Media. Yo gyakarta. pp. 22-27. 